\title{
PLASMA NEUROMEDIATORS AND THE ENZYMATIC PROFILE OF SHEEP
}

\author{
B. PÁSTOROVÁ, J. BULECA, E. PILIPČINEC, E. ŠVICKÝ, J. SZAREK \\ University of Veterinary Medicine, Košice, Slovak Republic \\ Agricultural University, Kraków, Poland
}

Received October 12, 1999

Accepted November 22, 2000

\section{Abstract}

Pástorová B., Buleca J., Pilipčinec, E. Švický, J. Szarek: Plasma Neuromediators and the Enzymatic Profile of Sheep. Acta Vet. Brno 2000, 69: 277-280.

The study focused on the plasma norepinephrine and epinephrine and activity of selected plasma enzymes and LD isoenzyme spectrum in two sheep breeds (Slovak Merino and Improved Valachian) during the anoestrous period. Radioenzymatic method was used to determine the concentrations of plasma catecholamines. Statistically significant differences were found $(P<0.05)$ in concentrations of norepinephrine and epinephrine in favour of the Slovak Merino breed. Significantly increased enzyme activies $(P<0.01)$ were observed in plasma aminotransferases ALT, AST and alkaline-phosphatase (ALP) in Slovak Merino. In improved Valachian, statistically significant changes $(P<0.01)$ were recorded in the activity of lactate dehydrogenase (LD). The LD isoenzyme spectrum showed statistically significant differences $(P<0.05)$ in the activity of isoenzyme LD2 and highly significant differences $(P<0.01)$ in the activity of isoenzymes LD4 and LD5 in favour of Improved Valachian sheep. These results may help to identify more accurately the metabolic constitutional and production types of sheep in different breeds.

Catecholamines, blood plasma, AST, ALT, CK, ALP, LD, isoenzymes LD1-5, sheep

Our previous results and the data of other authors suggest that the qualitative and quantitative changes in the composition of blood and its components may serve as indicators of the physiological state of the organism and characterise the metabolic and constitutional types of farm animals. In relation to genetic variability and heredity of production characteristics of farm animals, some authors (Glazko 1990; Al-Sadi 1995) have paid attention also to those physiological and biochemical indices that can be used to characterize the phenotype of individual animal-breeding taxons. These parameters also indicate the health state and vitality of animals (Jelínek et al. 1987; Hooda and Nagvi 1990; Goldberg 1992; Nagvi et al. 1991).

The concentration of catecholamines in the blood plasma reflects the activity of the adrenergic system. Plasma dopamine and norepinephrine are released from presynaptic adrenergic neurons (S a a vedra et al. 1984) and plasma epinephrine acts as a stress hormone and is produced by adrenal medulla. The plasma catecholamine concentrations in sheep depend on many factors including the level of oestrogens, the oestrous cycle (Miyake et al. 1987; Pástorová and Várady 1992, 1996) and the immune state (Pástorová et al. 1997) of the organism.

The present study focused on the plasma norepinephrine and epinephrine concentrations in the breeds Slovak Merino and Improved Valachian sheep in the anoestrous period as related to other biochemical indices, namely the activities of enzymes AST, ALT, CK, ALP, $\mathrm{LD}$, isoenzymes $\mathrm{LD}_{1}-\mathrm{LD}_{5}$. In addition to the clinical application of these physiological parameters for evaluation of the health state of animals they can be used to identify more accurately the constitutional and production types of animals.

Address for correspondence:

Doc.RNDr.Bernadetta Pástorová, $\mathrm{PhD}$.

Department of Physiology

Komenského 73, 04181 Košice, Slovak Republic
Phone: +421956338249

Phone: +421956338249

E-mail: pastor@uvm.sk

http://www.vfu.cz/acta-vet/actavet.htm 


\section{Materials and Methods}

The concentration of catecholamines was determined in the blood plasma of intact animals aged 2-4 years with average body weight of $41 \pm 1,8$ (SM) and $51 \pm 2,3 \mathrm{~kg}$ (IV). A total of 33 Slovak Merino (SM) and 20 Improved Valachian (IV) sheep were examined. The concentration of catecholamines was determined in blood obtained by catheterization of the jugular vein between 0800 and $0900 \mathrm{~h}$. The feed ration consisted of silage, fodder beet, hay, straw and feed mixture BAK. Water and salt were offered ad libitum. Glutathione $\left(0.05\right.$ mol. $\left.1^{-1}\right)$ in the amount of $20 \mu \mathrm{l} / 1 \mathrm{ml}$ blood was used as a stabilisator. The blood was centrifuged at 2000 r.p.m. and $4^{\circ} \mathrm{C}$ for $20 \mathrm{~min}$. Pure nonhaemolytic plasma was stored for a short time at $-70^{\circ} \mathrm{C}$ pending analysis. Catecholamines were determined in duplicate by a radioenzymatic method according to John s on et al. (1980) using 50Tl plasma aliquots. Radioactive derivatives were extracted and isolated by adsorption chromatography and the radioactivity was measured employing a scintillation spectrometer Packard Tri Carb in the ${ }^{3} \mathrm{H}$ channel. The sensitivity of the method for the $50 \mu \mathrm{l}$ aliquots was $0.37-4.00 \mathrm{pmol} . \mathrm{ml}^{-1}$ for norepinephrine and epinephrine. Blood serum was obtained for determination of activities of aspartate aminotransferase (AST), alanine aminotransferase (ALT), creatine kinase (CK), alkaline phosphatase (ALP), lactate dehydrogenase (LD), and its isoenzyme spectrum. To determine the isoenzyme spectrum, we separated LD on 5.5\% polyacrylamide gel by PAGE vertical electrophoresis according to the method by Dietz and Lubrano (1967). The electrophoreogrammes were evaluated densitometrically at $589 \mathrm{~nm}$ using an automatic regimen DS-90. The results were evaluated statistically by the non-paired Student's $t$-test.

\section{Results}

The concentration of norepinephrine and epinephrine in the plasma of both breeds under study are presented in Table 1. Both catecholamines were lower in Improved Valachian sheep.

Table 1

Concentration of plasma catecholamines and selected parameters of sheep serum enzymatic profile (mean values)

\begin{tabular}{|l|c|c|}
\hline Parameters & $\begin{array}{c}\text { Slovak Merino } \\
(\mathrm{n}=33) \pm \text { S.E.M. }\end{array}$ & $\begin{array}{c}\text { Improved Valachian } \\
(\mathrm{n}=20) \pm \text { S.E.M. }\end{array}$ \\
\hline norepinephrine $\left(\mathrm{pmol} \cdot \mathrm{m}^{-1}\right)$ & $1.45 \pm 0.17^{*}$ & $1.20 \pm 0.10$ \\
\hline epinephrine $\left(\mathrm{pmol} \cdot \mathrm{ml}^{-1}\right)$ & $1.50 \pm 0.11^{*}$ & $1.10 \pm 0.09$ \\
\hline AST $\mu$ kat. $\mathrm{l}^{-1}$ & $0.37 \pm 0.09^{* *}$ & $0.28 \pm 0.07$ \\
\hline ALT $\mu \mathrm{kat.}^{-1}$ & $0.85 \pm 0.18^{* *}$ & $0.71 \pm 0.15$ \\
\hline CK $\mu$ kat. $\mathrm{l}^{-1}$ & $0.16 \pm 0.06$ & $0.18 \pm 0.05$ \\
\hline AF $\mu$ kat. $\mathrm{l}^{-1}$ & $0.89 \pm 0.19^{* *}$ & $0.66 \pm 0.15$ \\
\hline LD $\mu$ kat. $\mathrm{l}^{-1}$ & $5.18 \pm 1.18$ & $7.13 \pm 1.80^{*}$ \\
\hline
\end{tabular}

$* \mathrm{p}<0.05, * * \mathrm{p}<0.01$

Table 2

Mean values of lactate dehydrogenase isoenzymes in the blood plasma of sheep

\begin{tabular}{|l|c|c|}
\hline Parameter & SM $(\mathrm{n}=33) \pm$ S.E.M. & IV $(\mathrm{n}=20) \pm$ S.E.M. \\
\hline LD1 \% & $62.22 \pm 3.11$ & $59.27 \pm 8.12$ \\
\hline LD2 $\%$ & $8.77 \pm 1.39$ & $9.87 \pm 1.54 *$ \\
\hline LD3 \% & $23.36 \pm 2.04$ & $21.98 \pm 4.20$ \\
\hline LD4 \% & $3.33 \pm 1.60$ & $5.08 \pm 2.41 * *$ \\
\hline LD5 \% & $2.31 \pm 1.02$ & $3.63 \pm 1.67 * *$ \\
\hline
\end{tabular}

*p $<0.05, * * \mathrm{p}<0.01$

Characteristic activities of plasma enzymes are presented in Table 1 showing significantly higher activities of AST, ALT and ALP in Slovak Merino sheep as compared to Improved Valachian breed $(P<0.01)$. The activity of $\mathrm{CK}$ did not show significant differences. Interbreed differences of LD were significant $(P<0.01)$ in favour of Improved Valachian. 
The evaluation of the results presented in Table 2, i.e. the LD isoenzyme spectrum showed significant differences $(P<0.05)$ in the activity of isoenzyme $\mathrm{LD}_{2}$ and highly significant differences $(P<0.01)$ in the activity of isoenzymes $\mathrm{LD}_{4}$ and $\mathrm{LD}_{5}$ between Slovak Merino and improved Valachian sheep breeds.

\section{Discussion}

Blood plasma catecholamines participate in regulation of various physiological mechanisms and may reflect several aspects of current animal states (physical and psychical stress, action of drugs), the influence of prolonged changes (hypertension, neural disorders) as well as the activity of the peripheral adrenergic system (R a u sch 1989; Tobias et al. 1963; Pástorová et al. 1994, 1996). Our experiment showed marked inter-breed differences in the concentration of plasma norepinephrine and epinephrine. Similarly, noticeable changes were reported by other authors, particularly in lambs (R ausch et al. 1996).

Determination of AST and ALT transaminases is very important for clinical diagnostics. AST in as intracellular enzyme released into the blood circulation following cell damage.

A number of tissues is innervated with postganglionic neurons of the sympatic nervous system that uses norepinephrine ans a mediator. Blood plasma norepinephrine originates in adrenergic neurons and epinephrine in the adrenal gland (S a avedra et al. 1994), and the levels of both of them increase in various pathological states resembling the changes in the above-mentioned enzymatic activities. Therefore it is essential to determine the physiological levels of catecholamines and enzymes in various breeds of sheep.

Except for CK, the differences found in all other enzymes between Slovak Merino and improved Valachian sheep, were significant. The values of these enzyme activities were within the reference range which is rather wide even for the physiological state. Our results agree with those of Vrzgula et al. (1990), Fesus et al. (1991) and Goldberg (1992). A common characteristics of the selected enzymes in the groups is their high variability which is most likely caused by instability of blood plasma indices. We obtained information on changes in these indices as related to breed for the two breeds under study. Our results confirm those of Goldberg (1992) showing that the animals with higher growth rates exhibit higher activities of plasma enzymes AST, ALT and ALP as reflected not only in morphological variables such as the weight gain but also in physiological characteristics. In this context we can agree with the opinion of Nagvi et al. (1991) that the phylogenetic origin of animals affects also the enzymatic values and the activity of plasma enzymes is included among those interior features which could be used to characterise the metabolic and production types of animals.

The inter-breed proportion of isoenzymes in the blood plasma of sheep was also studied by Šutiaková et al. (1993). The quantitative proportion of isoenzymes was determined by Michálek and Marcaník (1975) and Preus et al. (1989). Our results agree with those of the latter authors. Šutiaková et al. (1993) also observed significant $(P<0.01)$ differences between Slovak Merino and Improved Valachian sheep. When comparing our results with those of other authors it becomes clear that in addition to the use of physiological variables in clinical practice for evaluation of the health state of animals they can be used effectively also for more accurate identification of the metabolic constitutional and production types of animals.

Important examinations frequently requested by veterinarians include assessment of catalytic enzyme concentrations in different body fluids. In conjunction with unification of laboratory examinations there is an increasing necessity for reference intervals obtained by standard laboratory procedures (Malý and Sekaninová 1995). The values of the enzymes in our study were in agreement with their data. 


\section{Neuromediátory a enzymy v krvnej plazme oviec}

Rádioenzymatickou metódou sme stanovili hladiny plazmatických katecholamínov u dvoch typove rozdielnych plemien oviec Slovenské merino a Zušlachtená valaška $\mathrm{v}$ anestrickom období. Zistili sme, že hladiny norepinefrínu a epinefrínu vykazujú u plemena Slovenské merino signifikantne vyššie rozdiely $(P<0.05)$ oproti plemenu Zušlachtená valaška. Podobne u plemena Slovenské merino sme evidovali vyššiu aktivitu enzýmov aminotransferáz ALT, AST a alkalickej fosfatázy (AF). Aktivita enzýmu laktátdehydrogenázy (LD) bola štatisticky preukázne vyššia $(P<0.01)$ u plemena Zušlachtená valaška. Taktiež aj u izoenzýmového spektra LD sme zaznamenali štatisticky významné rozdiely $(P<0,05)$ v aktivite izoenzýmu $\mathrm{LD}_{2}$ a vysoko signifikantné rozdiely $(P<0,01) \mathrm{v}$ hodnotách izoenzýmov $\mathrm{LD}_{4} \mathrm{a} \mathrm{LD}_{5} \mathrm{v}$ prospech plemena Zušlachtená valaška.

\section{References}

AL-SADI, B. K. H. 1995: Some biochemical parameters in the blood serum of selected Awasi sheep. Ir. J. Vet. Sci. 8: $217-221$

DIETZ, A. A., LUBRANO, T. 1967: Separation and quantitation of lactic dehydrogenase isoenzymes by disc electrophoresis. Analyt. Biochem. 20: 246-257

GODDAR, J. 2000: Some plasma enzymes in different breeds of sheep. Appl. Anim. Behav. Sci. 66: 305-309

GLAZKO, V. I. 1990: Us of genetic distance to evaluate the genetic differentiation of breeds and lines. Vestnik Selskozhozyaistvennoi Nauki Moskva 12: 34-42

GOLDBERG, D. M. 1992: Enzymes as agents for the treatment of disease. Clin. Chim.Acta. 206: 45-76

HOODA, O. K., NAGVI, S. M. K. 1990: Changes in some blood constituents in different breeds of sheep exposed to elevated temperature and feed restriction. Ind. Vet. J. 67: 1121-1125

JELÍNEK, P., FRAIS, Z., ILLEK, J., HELÁNOVÁ, I. 1987: Selected biochemical values in blood plasma of rams and lambs during rearing (In Slovak). Ziv. výr. 32: 525-547

JOHNSON, G. A., KUPIECKI, R. M., BAKER, C. A. 1980: Single isotope derivate radioenzymatic measurement of catecholamines. Metabolism 29 (Suppl 1):1106-1113

MALÝ, M., SEKANINOVÁ, S. 1995: Intervaly referenčních hodnot enzymů pro vybrané druh hospodářských zviřat. Klin. Biochem. Metab. 24: 145-150

MICHÁLEK, A., MARCANÍK, J. 1975: Values of serum lactic acid dehydrogenase isoenzyme activities in farm animals (In Slovak). Vet. Med. (Praha) 20: 199-205

MIYAKE, A., NISHIZAKI, T., ATSUKA, S. 1984: Absence of effect of estrogen of catecholamines in human plasma. Endocrinol. Jpn. 34: 789-792

NAGVI, S. M. K., HOODA, O. K., PURNIMA-SAXENA 1991: Some plasma enzymes of sheep under thermal nutritional and exercise stresses. Indian Vet. J. 68: 1045-1047

PÁSTOROVÁ, B., VÁRADY, J. 1992: Catecholamine blood levels in sheep during superovulation in estrus. Vet. Med. Czech 37: 101-107

PÁSTOROVÁ, B., VÁRADY, J. 1994: The effect of hormonal superovulatory preparation FSH on the levels of catecholamines in the blood plasma of sheep. Physiol. Res. 45: 125-129

PÁSTOROVÁ, B., VÁRADY, J. 1996: Catecholamine levels and activity of monoamine oxidase in some hypothalamic structures of sheep after administration of FSH. Physiol. Res. 47:131-136

PÁSTOROVÁ, B., ŠTEVKOVIC M., RYBOS, M., ELIAS, V. 1997: The catecholamine levels in the blood plasma of rabbits naturally infected by Encephalitozzon cuniculi. Helmintológia 34: 222-226

PREUS, M., KARSTEN, A., BHARGAVA, A. 1989: Serum isoenzyme pattern of creatine kinase and lactate dehydrogenase in various animal species. J. Clin. Chem. Clin. Biochem. 27: 787-790

RAUSCH, W.D., HOPER, A., GEMEINER, M.1989: Katecholamin und Kortisolkonzentrationen in Plasma von Rindern um die Geburt. Zbl. Vet. Med. 36: 218-224

SAAVEDRA, J. M., CHEVILLARD, C., BISSERBE, J. C., BARDEN, N. 1984: Estradiol increases dopamine turnover in intermediate levels of ovariectomized rats. Cell. Mol. Neurobiol. 4: 397-402

ŠUTIAKOVÁ, J., DALLIOVÁ, K., ŠUTIAK, V., PIJÁKOVÁ, N. 1993: Lactate dehydrogenase isoenzymes in breeding sheep and ram lambs (In Slovak). Vet. Med. Czech. 38: 609-617

TOBIAS, N., CARR, L. A., WOOGHT, T. 1993: Catecholamine metabolism and the feedback effect of oestradiol benzoate on the release of LH and prolactin. Proc. Soc. exp. Biol. Med. 174: 284-290

VRZGULA L. et al. 1990: Metabolism disorders in farm animals and their prevention. (In Slovak) Natura, Bratislava, $495 \mathrm{p}$. 